\title{
A STUDY ON THE MATHEMATIC STUDENTS' DIFFICULTIES IN LEARNING ENGLISH AT EDUCATION STUDY PROGRAM OF FKIP USN KOLAKA
}

\author{
Netty Huzniati Andas \\ Universitas Sembilanbelas November Kolaka \\ ilamsmommy8631@gmail.com
}

\begin{abstract}
This research was a descriptive research with qualitative approach. It aimed to investigate the difficulties faced by class A students in the Mathematics Education Study Program in mastering four English language skills (Speaking, Writing, Reading, and Listening). The subjects in this study consisted of 26 students who were selected by purposive sampling. To obtain the data, The researchers used two instruments, namely interviews and questionnaires. Questionnaires were distributed to students to find out the information about students' difficulties, while interviews were submitted to informants to clarify information obtained from the questionnaires. The data were analyzed through three stages; data reduction, data presentation, and drawing conclusions or verification. The results showed that most of the students had difficulties when they learnt English such as lack of vocabulary, low grammar mastery, and pronounciation. These three problem were regarded as the obstacles to them to perform the four English skills. In addition, facilities in learning as well as techniques or methods used by lecturers in the teaching and learning process became the factor influenced students in mastering English.
\end{abstract}

Keywords: English, Language Learning Difficulties, Vocabulary, Grammar, Pronunciation

\section{BACKGROUND}

English is one of the foreign languages in Indonesia. The Government of Indonesia through the Ministry of Education and Culture issued Decree No. 096/1967 on 12 December 1967 which stated that English was the first foreign language implied through the curriculum of primary, secondary, and tertiary education. In addition, English is also a compulsory subject that must be given to students because English is one of the requirements to face global demands.

In the current development, mastering English is a need to face global progress, especially after Indonesia has been established as a member of the AEC (ACEAN Economic Community), it is fitting for the Indonesian people to be more advanced and be able to compete with other countries in terms of science and technology supported also by the mastery of good and correct language of instruction. By seing at the role and function of English in every line of community life, it is not surprising that Government Regulations

\section{British, Jurnal Bahasa dan Sastra Inggris}


make English as a subject that must be mastered starting from elementary school to tertiary level (Hermawati, 2010).

In the tertiary level, teaching English cannot ignore the mastery of four language skills such as Listening, Reading, Writing, and Speaking which are taught integratively with the aim that students are able to communicate using English correctly both in oral and written form. Moreover, to achieve optimal English Language ability, learners must also be able to master the three elements that play an important role in supporting the four language skills, such as; pronunciation, vocabulary, and language structure or grammar (Megawati, 2016).

In the Mathematics Education Study Program of FKIP USN Kolaka, based on the curriculum, English is the mandatory subject of the University which is taught for 2 semesters namely English I in semester one and English II in semester two with 2 Semester Credit Units (SKS) per week. This time allotment is expected to help the students master English well and simultaneously will open their horizons to the development of science and technology, including education which is now easily accessible from various sources.

However, this is not in line with the achievement performed by the students in learning English. Based on the results of preliminary observation, researcher found an indication of the quality of English mastery of Mathematics Education Study Program students was still very low. Besides, the lecturer employed the learning materials by using the simplest English instruction. For example, they use Indonesian language in teaching and learning process. It also found that most students were not actively involved in the English learning process; they tended to be passive in accepting material so that lecturer was dominated in the classroom activities.

Another indication was that the students' interest in improving their English skills were very lack. For example, when the instructor instructs them to have a simple conversation, students stay quiet without doing the activit. Also, they are not able to understand the contents of the simple reading text given by the lecturer.

The lack of students' motivation in learning English became a trigger for them to neglect the assignments given by the lecturer. Many students did not bring English dictionaries and textbooks during the teaching and learning process and did not memorize

\section{British, Jurnal Bahasa dan Sastra Inggris}


vocabularies related to the learning material. Thus, it can be concluded that students of Mathematics Education Study Program still experience various obstacles and difficulties in mastering four English skills even though they have learned these skills for six (6) years; since at the junior and senior high schools.

Based on the above phenomenon, the researcher considers it is necessary to analyze the difficulties faced by students of the Mathematics Education Study Program in mastering English which includes speaking, writing, reading, and listening because these difficulties greatly affect the student's learning outcomes. In addition, researcher also find out the factors behind the emergence of these difficulties and what efforts can be done to overcome these difficulties. Thus, the results of this study can be used to improve the concept of effective English learning for students, especially students of the Mathematics Education Study Program FKIP USN Kolaka.

\section{METHOD OF RESEARCH}

This research was a descriptive research form with a qualitative approach, as many as 26 students of Class A Mathematics Education Study Program are the subjects. To obtain data, researcher used two instruments namely; interview and questionnaire. Interview is a primary data collection technique that is used to obtain accurate and relevant data by asking questions to informants about the problem being investigated, responses from informants will be recorded using an audio recording tool. The type of interview conducted is a semi-structure interview. Meanwhile, data collection through a questionnaire is used as supporting data (secondary data) to support the results of primary data (interviews). To obtain information about problems in this study, researcher distributed questionnaires to informants in the form of close-ended and open-ended questionnaires. As

for the data analysis, it consists of three stages, namely; Data reduction, data presentation, and drawing conclusions or verification.

\section{FINDING AND DISCUSSION}

This presents data from questionnaires and interviews about the problems of the students in learning English, the factors behind the emergence of the problem, and what efforts must be done to overcome the problem.

\section{British, Jurnal Bahasa dan Sastra Inggris}




\section{Finding}

\section{Problems in Speaking}

The following are the results of the questionnaire analysis about the problems faced by students in speaking. For more details can be seen in the table below.

Tabel 1. Student problems in speaking

\begin{tabular}{ccccl}
\hline NO & Statement & Mean & SD & Kategory \\
\hline $\begin{array}{l}\text { 1. I feel anxious when I have to } \\
\text { speak English }\end{array}$ & 26 & 2,92 & 0,483 & Problems \\
& & & 5764 & \\
\hline 2. I am not confident in the way I & 26 & 2,57 & 0,757 & $\begin{array}{l}\text { Troubled } \\
\text { speak English that is thick with } \\
\text { my native language. }\end{array}$ \\
\hline 3. I have difficulty reciting English \\
$\begin{array}{l}\text { speech that has no equivalent in } \\
\text { my native language. }\end{array}$
\end{tabular}

From the table above, we can see that in general students have problems in speaking English. First, the problem students face when speaking in English is anxiety by an average of 2.92 and is included in the "Troubled" category. This can also be seen in the results of the interview;

.....Ya bu karena alasan pertama saya merasa cemas karena kosa kata yang saya punya itu sangat sedikit bu....

Appendix/wawancara I/ B1/

From the results of the questionnaire and interview above we can conclude that the factors that cause students to feel anxious in speaking English are vocabulary because the less vocabulary they have the more anxious they are to speak English. Then from the results of the interview also found that another factor that caused them worry about speaking was the grammar.

\section{Problems in Listening}

The table below will present the problems faced by students in listening.

\section{British, Jurnal Bahasa dan Sastra Inggris}


Tabel 2. Student Problems in Listening

\begin{tabular}{|c|c|c|c|c|c|}
\hline No & Pernyataan & $\mathbf{N}$ & Mean & SD & Kategory \\
\hline 1. & $\begin{array}{l}\text { I have difficulty listening } \\
\text { when the speaker uses } \\
\text { language or vocabulary that is } \\
\text { not standard in English }\end{array}$ & 26 & 3,26 & $\begin{array}{l}0,6667 \\
9486\end{array}$ & $\begin{array}{c}\text { very } \\
\text { problematic }\end{array}$ \\
\hline 2. & $\begin{array}{l}\text { I have difficulty listening } \\
\text { when the speaker is talking } \\
\text { too fast. }\end{array}$ & 26 & 3,38 & $\begin{array}{l}0,6373 \\
02\end{array}$ & $\begin{array}{c}\text { very } \\
\text { problematic }\end{array}$ \\
\hline 3. & $\begin{array}{l}\text { I have difficulty listening } \\
\text { when the speaker uses an } \\
\text { English accent or dialect that } \\
\text { I rarely listen. }\end{array}$ & 26 & 3,15 & $\begin{array}{l}0,6126 \\
86\end{array}$ & Problems \\
\hline 4. & $\begin{array}{l}\text { When the lecturer plays audio } \\
\text { listening, the quality of } \\
\text { teaching material (the } \\
\text { recording is not very clear) or } \\
\text { the speaker often affects my } \\
\text { understanding of listening. }\end{array}$ & 26 & 3,53 & $\begin{array}{l}0,5817 \\
74474\end{array}$ & $\begin{array}{c}\text { very } \\
\text { problematic }\end{array}$ \\
\hline
\end{tabular}

From the results of the questionnaire above, it can be concluded that students experience many problems in English, especially in listening skill. In the first statement that students have difficulty in listening to words that are not standard, the average obtained by students is 3.26, including the category "very problematic". From the interview results it is known that the underlying factor for this problem is the sound equation in several English words.

......Biasa itu date yang tanggal dengan dead atau mati. Kalau hurufnya disebutkkan itu tidak jelas kita salah persepsi dalam kosakatanya yang seharusnya tadi tanggal bisa jadi mati dan bia jadi artinya saling berkebalikan.......

Appendix/Wawancara II/B2/

In the second statement, the students found it difficult to listen when the speaker spoke too fast with an average of 3.38 in the "very problematic" category. The results of the interview show that the factors underlying this are a number of letters that contain or fuse together. 


\section{Problems in Reading}

The table below presented the problems faced by students in reading.

Tabel 3. Student Problems in Reading

\begin{tabular}{cllllc}
\hline No & \multicolumn{1}{c}{ Statement } & N & Mean & SD & Category \\
\hline 1. & $\begin{array}{l}\text { I have difficulty understanding } \\
\text { the text I read because of my } \\
\text { limited vocabulary in English. }\end{array}$ & 26 & 2,73 & 0,777 & $\begin{array}{c}\text { Troubled } \\
\text { enough }\end{array}$ \\
\hline 2. & $\begin{array}{l}\text { I have difficulties in } \\
\text { understanding the text that I } \\
\text { read due to low grammatical. }\end{array}$ & 26 & 2,92 & 0,483 & Problems \\
3. & $\begin{array}{l}\text { I am not interested in reading } \\
\text { English texts because the } \\
\text { topics are less interesting to } \\
\text { me. }\end{array}$ & & 2676 & \\
\hline
\end{tabular}

The table above shows that students still experience some problems with reading skills. As seen in the first statement, it is difficult for students to understand reading texts with an average value of 2.73 , including the "Troubled enough" category.

Sulit bu karena kalau kosa kata kita sedikit kan banyak itu di teks kosakata baru... Jadi kosa kata baru itu yang kita susah kita temuakan artinya jadi pas membaca kita sudah tidak tau mi apa maksudnya.

\section{Appendix/Wawancara I/B3/}

In the second statement, the problem experienced by students when reading is due to a lack of understanding of English grammar with an average value of 2.92 in the "problematic" category.

\section{Problems in Writing}

The table below will present the problems faced by students in writing.

Tabel 5. Student Problems in Writing

\begin{tabular}{clllll}
\hline No & \multicolumn{1}{c}{ Statement } & N & Mean & SD & Category \\
\hline \multicolumn{1}{c}{ 1. I can't write English well } & 26 & 2,65 & 0,745 & $\begin{array}{l}\text { Troubled } \\
\text { enough }\end{array}$ \\
$\begin{array}{l}\text { because of my limited } \\
\text { vocabulary. }\end{array}$ & & & 241 & \\
\hline 2. I can't write English well \\
$\begin{array}{l}\text { because of my low grammatical } \\
\text { mastery. }\end{array}$ & 26 & 2,73 & 0,724 & $\begin{array}{l}\text { Troubled } \\
\text { enough }\end{array}$ \\
\hline
\end{tabular}

British, Jurnal Bahasa dan Sastra Inggris 


\begin{tabular}{llllc}
\hline 3. When writing, I have difficulty & 26 & 2,53 & 0,760 & Troubled \\
on how to start an article / idea. & & & 567 & \\
\hline 4. My problem in English arises \\
because the time available for \\
$\begin{array}{l}\text { English practice in the classroom } \\
\text { is very limited. }\end{array}$
\end{tabular}

The table above presents the results of the questionnaire to find out the problem of students in writing skills, the first statement found that students could not write well in English because of limited vocabulary with an average value of 2.65 included in the category of "Fairly problematic". this is also seen in the results of the interview.

Karna masalah kosakata bu...bahasa inggris kn perlu kosakata, jadi walupun kita sudah tulis pake bahasa Indonesia terus klo tidak ada kosakata bagaimana kita mau tulis bahasa inggrisnya

Appendix/Wawancara I/B4/

In the second statement the problem faced by students when writing is low grammar mastery with an average value of 2.73 including the Troubled enough Category.

\section{Discussion}

From the results of questionnaire and interview analysis, it found that the problems of students in learning English were vary. In Speaking skill, there are three problems faced by students, namely; anxiety when speaking English, lack of confidence to speak in English, and stuttering. The problem is caused by several internal factors such as the lack of vocabulary of students which makes it difficult for them to convey the ideas they want to deliver, the second factor is the lack of grammar mastery that makes them reluctant to speak English because they are afraid of making mistakes if their speech does not match good and correct grammar, the third factor is lack of ability in pronunciation in English.

The pronunciation factor can make students stuttered to express their opinions in English due to differences in language sounds between Indonesian and English (Hermawati, 2010).

In Listening skill, the problems faced by students are as varied as the existence of non-standard vocabulary in oral texts, the narratives from the audio that are too fast, and the 
use of dialects that are rarely heard by students. Internal and external factors are that greatly affect student understanding when they do listening to oral texts in English. Internal factors in listening skill is also called linguistic factors, which means the inability of students to identify the sounds of language in spoken form because they thought that there are several words in English when they pronounced are almost sound similar such as in words "date" and "dead". In English this term is known as the minimum pairs. Furthermore, the factors that influence students' understanding listening are external factors which include nonlinguistics. On this factor, students have difficulty in understanding oral texts due to the quality of teaching materials provided by the teacher, such as unclear or even broken recordings when students listen to the oral texts (Siti, 2017).

In Reading Skill, problems experienced by students that are difficulty in understanding the meaning of reading texts and their lack of interest in reading English texts. The factors that influenced difficulties in understanding English reading texts are the lack of vocabulary and grammar mastery. Adequate vocabulary will be very helpful for understanding the reading text, however, the vocabulary owned by students is still very limite. They felt very difficult to understand the meaning of the text even they used the dictionary repeatedly to find the meaning of unfamiliar words. Similar to vocabulary problem, grammar are also very influential in understanding the meaning of reading text, because in English texts such as descriptive texts, narratives, and argumentative texts have different language settings. In addition, another factor that hinders students' understanding of reading skills is their lack of interest in reading English text. This is also caused by the lack mastery of vocabulary and grammar so that students tend to be lazy to search for or even read English text (Sabouri, 2016).

In writing skill, the problem faced by students is lack of vocabulary mastery, and the lack of ability in generating idea in English. Writing is a very complex skill, because to produce good writing not only mastery of vocabulary is needed but also good and correct grammar mastery is needed as well to make our writing clear and easily understood by readers. A person can write with the aid of a dictionary when they deal with unfamiliar words. But the meaning of his writing may not be conveyed clearly because it does not use good grammar (Fareed, Ashraf, and Bilal, 2017).

\section{British, Jurnal Bahasa dan Sastra Inggris}


In general, efforts that must be done to overcome these problems are as follows; provide adequate time for students to practice four language skills. Furthermore, lecturers provide more opportunities for students to be actively involved in every activity in the class. The last, lecturers should apply methods that are appropriate to the situation, conditions and learning needs.

\section{CONCLUSION AND SUGGESION}

Based on the results of the questionnaire analysis and interviews it was concluded that the problems of Mathematics Education Study Program students in learning English were very varied as well as the factors underlying the emergence of the problem. In Speaking skills, the main problems faced by students are anxiety, lack of confidence, and stuttering. The factors that influence this problem are lack of vocabulary, lack of grammar mastery and poor pronunciation. Furthermore, on Listening skill the problems experienced by students are the existence of non-standard vocabulary in oral texts, narratives that are too fast, and the use of dialects that are rarely heard by students; while the influencing factors are linguistic and non-linguistic factors when listening to oral texts in English. Then in reading skill, problems experienced by students are difficulty in understanding the meaning of reading texts and their lack of interest in reading English text, the factors that influence these problems arise are lack of vocabulary and lack of grammar mastery. Finally, in the writing skill, the problems and factors faced by the students are the lack vocabulary and grammar mastery, and lack of ability in generating idea in English.

\section{REFERENCES}

Asriati, Siti. 2017. Factors Affecting Listening Comprehension Achievement of Students. Universitas Muhammadiyah Makassar: Thesis.

Fareed, Muhammad. Ashraf, Almas, Bilal, Muhammad. 2016. ESL Learners' Writing Skills: Problems, Factors and Suggestions.

Gilakjani \& Sabouri. 2016. A study of Factors Affecting EFL Learners' Reading Comprehension Skill and the Strategies for Improvement. International Jurnal of English Linguistics 6(5)

\section{British, Jurnal Bahasa dan Sastra Inggris}


Hermawati, 2010, Analisis Kesulitan Belajar Bahasa Inggris Mahasiswa. Jurnal SosioHumaniora, 1(1), 2087-1899.

Megawati, F., Mandarani, V. 2016. Speaking Problems in English Communication. Artikeldipresentasikanpada the First ELTiC Conference. Universitas Muhammadiyah Purworejo, Jawa Tengah. 30 Agustus 2016.

Sugiyono, M.P.P.P.K. 2010. Kulitatif, dan R dan D. Bandung: Alfabeta.

Pollard, Lucy. 2008. Guide to Teaching English. UK: Longman.

Syahputra, Idham. 2014. Strategi Pembelajaran Bahasa Inggris Sebagai Bahasa Asing Dalam Meningkatkan Kemampuan Berbahasa Siswa. Jurnal Penelitian sosial keagamaan, 23(2)

Tariq, Rehman. Bilal, Hafiz. Sandhu, Muhammad 2013. Dfficulties in Learning English As A Second Language in Rural Areas of Pakistan. Academic Research International 4(6).

Yuliantini, Ni Nyoman. 2013. Studi Tentang Faktor-Faktor Penghambat Proses Belajar Mengajar Bahasa Inggris di Kelas II SMPN 1 Kuta Utara dan SMP Budi Utama Kerobokan Berdasarkan Kurikulum 2004. Jurnal Sosio-Humaniora 3(2). 